\title{
The involvement of non-state actors in the creation and management of protected areas: insights from the Portuguese case
}

\section{Giulia Iannuzzi, Rui Santos \& João Morais Mourato}

To cite this article: Giulia lannuzzi, Rui Santos \& João Morais Mourato (2019): The involvement of non-state actors in the creation and management of protected areas: insights from the Portuguese case, Journal of Environmental Planning and Management, DOI: 10.1080/09640568.2019.1685475

To link to this article: https://doi.org/10.1080/09640568.2019.1685475

曲 Published online: 15 Nov 2019.

Submit your article to this journal $₫$

Џ Article views: 67

Q View related articles $\asymp$

View Crossmark data $₫$ 


\title{
The involvement of non-state actors in the creation and
} management of protected areas: insights from the Portuguese case

\author{
Giulia Iannuzzi* (D), Rui Santos $^{\mathrm{a}}$ (D) and João Morais Mourato ${ }^{\mathrm{b}}$ \\ ${ }^{\mathrm{a}}$ CENSE - Center for Environmental and Sustainability Research, NOVA School of Science and \\ Technology, NOVA University Lisbon, Caparica, Portugal; ' ICS Institute of Social Sciences, \\ University of Lisbon, Lisbon, Portugal
}

(Received 7 February 2019; Revised 19 September 2019; final version received 22 October 2019)

\begin{abstract}
Increasingly, Protected Areas (PAs) are sustained by a multilevel governance where demands for public participation have occurred against the backdrop of state reconfiguration. Little scholarly attention has been paid to how these shifts have taken place; this paper aims to diachronically assess the involvement of non-state actors in the governance of PAs in Portugal. Our findings indicate that while the range of actors involved in the decision-making process has progressively widened, their engagement remains mainly consultative. Moreover, PAs managed by local authorities and private actors have been recognised, yet local authorities' involvement in PAs managed by state actors has been recently reduced. These apparently contradictory trends seem to illustrate a common rationale: state actors are fighting to retain control while adapting to the broadening role of multiple actors in nature conservation policies. We conclude that new governance approaches do not necessarily pave the way for more public participation in conservation.
\end{abstract}

Keywords: nature conservation; protected areas; public participation; private protected areas; environmental governance

\section{Introduction}

Over the past four decades, there has been an international paradigm shift towards more inclusive nature conservation policies. The first parks' exclusionary denial of indigenous peoples' rights has been gradually replaced by people-oriented approaches promoting participation by people in decisions affecting them (Corson et al. 2014; Berkes 2007). The growing demand for local community involvement has occurred in a context in which state authority has been reconfigured (Lockwood 2010; Rhodes 1996). State actors ${ }^{1}$ now share nature conservation endeavours with non-state actors, such as international organisations (e.g. United Nations), private actors (e.g. NGOs and market-oriented actors) and local authorities (Larsen and Brockington 2017). As a result, the participatory turn and the rescaling of governance have made networks of actors and their interplays, along spatial scales and interdependent levels of policy making, more complex (Paavola, Gouldson, and Kluvánková-Oravská 2009; Armitage, de Loë, and Plummer 2012).

A growing body of literature has focused on the diffusion of participatory practices which involve local stakeholders in nature conservation governance and the

*Corresponding author. Email: giuliaiannu@yahoo.it 
management of PAs (Rauschmayer, van den Hove, and Koetz 2009a; Niedziałkowski, Paavola, and Jędrzejewska 2012; Hovik, Sandstrom, and Zachrisson 2010; Ferranti et al. 2014). However, not much scholarly attention has been paid to the incremental opportunities for the wider array of non-state actors to engage throughout the different stages of the decision-making process encompassing the designation, implementation and management of a PA. In particular, there is a lack of systematic investigations into when and how their role has been recognised and promoted in policy and legal frameworks for PAs (Niedziałkowski et al. 2016). When did these changes materialise in institutional arrangements for PAs? Who can participate? How? Shedding light on these questions is crucial to better understand and discuss the implications of the shifting approaches for the governance of PAs and to critically explore the consequences of the changes concerning actors, their power and their interactions.

The aim of this paper is to contribute towards addressing this literature gap. Drawing on the framework developed by Niedziałkowski et al. (2016), we will conduct a systematic investigation into the involvement of non-state actors in nature conservation decision making regarding the design, implementation and management of PAs on the Portuguese mainland. Cumulatively, we will explore the correspondent reconfiguration of state actors' roles in the governance of PAs from a diachronic perspective. The method employed combines the analysis of national policy and legislative documents with the analysis of semi-structured interviews with officials from the PAs National Authority, NGO representatives and environmental policy experts. Portugal has been chosen as a case study since its evolving paradigm of nature conservation policies and opening up of PA governance is expected to entail great change and interesting implications in regard to the interactions of state and non-state actors. Indeed, the potential inclusion of non-state actors in the governance of PAs clashes headfirst with the Portuguese centralised top-down institutional heritage.

The article is structured as follows. The first part deals with the conceptual and the contextual frameworks. The second part presents methods used for data collection and analysis. The results of the analysis will then be detailed, preceded by an introduction to the history of Portuguese nature conservation policies. Finally, we will compare our findings with the international literature concerning PAs and discuss the implications of the identified trends of non-state actors' involvement in the governance of PAs.

\section{Setting the scene: towards people-centred protected areas?}

Since the late $1800 \mathrm{~s}$, early narratives of conservation were framed in terms of the preservation of pristine environments and minimising the impact of residents, who were excluded both politically and physically from parks. From the late 1970s onwards, the global diffusion of community-oriented models, designed to ensure public participation and to balance conservation with local needs, was prompted by the upsurge of indigenous people's movements and the emergence of the sustainable development concept, which bridged the environmental dimension with the social and economic ones (Jeanrenaud 2002). This participatory turn in PAs, has been underpinned by principles of participative and deliberative models of democracy (Mellinger and Floriani 2015). Public participation in environmental decisions has proven to be crucial for raising awareness on environmental issues, and for building local management capacity (Beierle and Cayford 2002). It has been argued that more inclusive 
models, thanks to their 'learning component,' promote the empowerment of participants in defining and meeting their own needs (Bulkeley and Mol 2003).

Besides contributing to the democratisation of the environmental decision-making processes, participation has a significant instrumental value. In fact, positive perceptions of governance are related to improved effectiveness in terms of nature conservation, as participation in natural resources management raises social acceptance and compliance levels (Hatcher et al. 2000). Consequently, it may reduce management costs, since voluntary compliance may eventually substitute expensive top-down enforcement (DeCaro and Stokes 2013). Moreover, participatory governance contributes to opening up the policy process, embracing diverse knowledge and values related to biodiversity, mitigating the limits of technocratic science-led solutions and leading to higher quality decisions (Reed 2008). These arguments have been classified as substantive motivations, complementing the above-mentioned instrumental and normative rationales (Wesselink et al. 2011).

Public participation, promoted in its diverse, though not always exclusive, facets is now incorporated into conservation agendas and integrated into legal instruments (e.g. the Aarhus Convention). Participation is nevertheless contested and its pitfalls have been pointed out (Rauschmayer, Paavola, and Wittmer 2009b; Turnhout, Van Bommel, and Aarts 2010). Firstly, it has been acknowledged that increased stakeholder involvement does not necessarily lead to the achievement of nature conservation goals (Young et al. 2013); for instance, participatory processes can be time consuming, causing a slow response to conservation issues (Rodríguez-Izquierdo, Gavin, and MacedoBravo 2010). Secondly, there is a critical gap between the paradigm shift in the agenda for conservation and its practice. For example, regarding the implementation of the EU Natura 2000 network, the policy process was mostly top-down and expertise driven (Rauschmayer, Paavola, and Wittmer 2009b). In Pellizzoni's words (Pellizzoni 2003, 213) the crucial question "is not how much participation, but what kind of participation, by whom, to which purposes." Indeed, power inequalities are barriers for effective participation, since previous marginalised groups may have limited power to influence decisions. Finally, critical analyses of participatory approaches note that in a post-political arena, which perceives conflict as something that should be avoided through consensus (Laclau and Mouffe 2001), participatory practices may degenerate into a technocratic exercise of problem solving (Cleaver 1999).

The promotion of local communities and other stakeholders' engagement in decisions affecting them has been accompanied by the incorporation of other non-state actors in the governing arena for nature conservation. This has taken place within a wider trend of increasing intricacy of actors' interactions with interdependent levels of policy-making, which have reconfigured state, markets and civil society interactions in public policy domains (Héritier 2010; Armitage, de Loë, and Plummer 2012). This trend is commonly referred to as a shift from "government to governance" (Knill and Lehmkuhl 2002; Kooiman 2003) or "rescaling of governance" (Apostolopoulou et al. 2014). Throughout this transition, state authority has witnessed a threefold rearrangement: i) upwards, with the delegation of power to international/transnational levels of governance (e.g. the European Union); ii) downwards to local state actors through decentralisation; and iii) sideways to the private sector (Rhodes 1996). As a result, in the field of nature conservation policies, the institutional landscape where PAs are currently embedded is characterised by polycentric governance (Lockwood 2010), a system in which a complex array of actors are organised into multiple centres of decision making. Partnerships between state 
and non-state actors (e.g. NGOs, local authorities) have taken the forms of co-design, coregulation or co-management (Bishop and Davis 2002).

In this multifaceted environment, a variety of institutional configurations and hybrid governance models have appeared with permeable boundaries between public and private dimensions. Advocates of new governance models have pointed out the opportunities for leveraging non-state actors' resources (e.g. knowledge, financial and human) as well as for gaining a new source of legitimacy (e.g. Langholz and Lassoie 2001). In this line, it has been highlighted that the opening up of decision making to a wider input by non-state actors does not necessarily trigger a loss of state power. Instead, the state would retain a steering role through softer tools than the traditional top-down regulatory ones, for example through fiscal conditioning or discursive framing to govern networks (Giessen et al. 2016).

On the other hand, a lack of funding and capacity for dealing with increasingly complex institutional settings may trigger a loss of steering ability for the state. Similarly, some scholars have warned of the growing economic opportunities for private actors within nature conservation policies, threatening public interest and disempowering local communities (Maestre-Andrés, Calvet-Mir, and Apostolopoulou 2018; Lane 2003). Furthermore, co-management solutions have been found to occasionally lead to the co-optation of community-based resource management and the reinforcement of local elites (Berkes 2009).

\section{Data collection and analysis}

To illustrate the involvement of non-state actors regarding the design, implementation and management of Portuguese PAs, we: (i) conducted a systematic review of national policy and legislative documents; (ii) carried out semi-structured interviews with representatives from the national administration, NGOs and local nature conservation policy experts. Using triangulation analysis, we integrated this data with literature on Portuguese PAs.

The period of analysis ranges from 1970 to 2015, specifically from the enactment of the first Protected Areas Act in 1970 to the amendment of the 2008 Decree-Law on Biodiversity and Nature Conservation, introduced in 2015. The key pieces of reviewed legislation are listed below:

(i) Protected areas Act n. 9/70, 19 June 1970: first Portuguese law on PAs;

(ii) Decree-Law n. 613/76, 27 July 1976, regulating the designation and management of PAs, and Decree n. 4/78 on PAs' management structures;

(iii) Decree-Law n. 19/93, 23 January 1993, creating the national network of PAs;

(iv) Decree-Law n. 221/2002, 22 October 2002, amendment to Decree-Law n. 19/93;

(v) Decree-Law n. 136/2007, 27 April 2007 and Decree n. 530/2007, of 30 April 2007, on internal organisation and competences of the reformed National Authority;

(vi. a) Decree-Law n. 142/2008, 24 July 2008, on Biodiversity and nature Conservation Juridical Regime;

(vi.b) Decree-Law n. 242/2015, 15 October 2015, amendment to Decree-Law n. $142 / 2008$.

The desk study was complemented with a total of 17 semi-structured interviews, conducted between 2016 and 2017, with: i) six representatives of state administration (i.e. officials or ex-officials of the National Authority responsible for nature 
conservation policies and the management of PAs); ii) seven environmental representatives $^{2}$ of NGOs; and iii) 4 key experts (i.e. scholars and representatives of the National commission on Environment and Sustainable Development ${ }^{3}$ ). Interviews lasted between one hour and one and a half hours; they were recorded and transcribed. The interviewees were chosen in view of the need to cover the period referred to above. In order to complement an initial list of respondents, we used the technique of snowball sampling. The aim was twofold: i) to validate the chosen policy framework and ii) to gather additional data to better trace the evolution of the roles of, and interactions between, state actors, local public actors and private actors (e.g. NGOs) in PAs' institutional settings.

The framework we employed to systematise and analyse the collected data is based on the one developed by Niedziałkowski et al. (2016) to investigate non-state actors' participation in Polish PAs. It was selected as it enables a systematic diachronic analysis of the involvement of different groups of actors during distinct phases within the governance of PAs. In particular, Niedziałkowski et al. $(2016,1897)$ identified five key legal issues underpinning the governance model of PAs: "(1) establishing a PA; (2) introducing restrictions; (3) creating management rules; (4) determining the organisation of the administration of PAs; (5) appointing a person in charge of the administration of PAs." Adapting this framework to the Portuguese context meant merging the last three issues into "defining the management rules." In sum, our analytical framework involves three distinct phases: i) designation of a PA; ii) introduction of restrictions on PA territory; iii) management structure.

The first phase (designation of a PA) refers to the creation of a PA, addressing the question: who is involved in the assignment of the designation of PAs? ii) The second phase (introduction of restrictions) encompasses: a) the adoption of PAs' spatial plans which define the objectives of the protection and the management of the site, listing all the activities prohibited or subjected to authorisation in each identified zone; b) or, other regulations defining restrictions. iii) The third phase (management structure) considers the criteria for the appointment and the composition, as well as the powers of management bodies (e.g. directive and consultative bodies), whenever explicated in the legislative acts.

Governance actors of PAs have been chosen according to the typologies identified in national legislation: i) state actors; ii) local authorities; iii) NGOs; iv) citizens; v) local landowners; vi) other stakeholders. The "citizens" category encompasses local communities and the general public. The category of "landowners" reflects the relevance of these stakeholders in a territory where private property is by far the most common land tenure. The "other stakeholders" category encompasses associations (e.g. socio-economic and cultural associations) and research institutions. Specifically, private companies are included in this category, as they are represented through organised interest groups in the governance of PAs. Note that the proposed categories may overlap; for instance, a national or local NGO or a private company may also be a landowner.

Different approaches and typologies of stakeholders' participation have been developed to analyse actors' contribution to decision making (see Reed 2008). Drawing upon Niedziałkowski et al. (2016) and on the ladder metaphor (Arnstein 1969), our scale for actors" involvement ranges from "no involvement" to "decision making" (Table 1). We refined the framework to adapt it to the typologies referred to in the Portuguese legislation on PAs. Specifically, unlike Niedziałkowski et al.'s (2016) study, we do not refer to the "information" typology of actors' involvement and we 
Table 1. Actors' involvement in the decision-making process.

\begin{tabular}{|c|l|}
\hline No involvement & $\begin{array}{l}\text { The actors are not referred in the legislation as participants } \\
\text { in the decision-making process }\end{array}$ \\
\hline Consultation & $\begin{array}{l}\text { A feedback by a particular group of actors is sought, however } \\
\text { inputs provided do not need to be followed }\end{array}$ \\
\hline Proposal & $\begin{array}{l}\text { The actors can initiate a decision-making process, however } \\
\text { the final decision on it depends on another actor consent }\end{array}$ \\
\hline Consent & $\begin{array}{l}\text { In order to take a specific decision the actors have to approve } \\
\text { it or agree on it }\end{array}$ \\
\hline Decision making & $\begin{array}{l}\text { The actors can initiate a binding decision-making process } \\
\text { and take a final decision on it }\end{array}$ \\
\hline Not applicable &
\end{tabular}

Source: Adapted from Niedziałkowski et al. 2016.

also add an intermediate step: "proposal," which denotes a situation where certain actors could initiate a decision-making process, but the final decision is dependent upon another actor altogether.

\section{Portugal as a case study}

In Portugal since the 1970s, PAs have been a key implementation mechanism for nature conservation policies. Portuguese PAs emerged within landscapes shaped by anthropogenic modifications resulting from traditional human activities and characterised by private land tenure. The first PAs were established in the early 1970s during Portugal's authoritarian regime under a context of pressures and opportunities at the international level (Soromenho-Marques 1998), and the absence of a diffused domestic interest in environmental concerns and political constraints on the actions of civil society organisations (Figueiredo, Fidélis, and Rosa Pirez 2001). For example, the Peneda Gerês National Park was created in 1971 following the "Wilderness model" of the first national parks in the United States. After the 1974 Revolution, the new democratic government created the Secretariat of State for the Environment and the National Service of Parks, Reserves and Landscape Heritage (hereafter the National Authority). This is the first, and only, National Authority responsible for the management of PAs to this day, despite multiple subsequent designations, organisational designs and competence framework changes.

The admission to the European Economic Community (EEC), in 1986, accelerated the development of policy and legal frameworks for nature conservation policies (Figueiredo, Fidélis, and Rosa Pirez 2001). In particular, the approval of the Environmental Framework $\mathrm{Law}^{4}$ in 1987 gave consistency to policy making in this 
sector and initiated the process of the transposition of EEC directives into national law, while the landmark Environmental Association Law ${ }^{5}$ (1987) boosted environmental NGOs' empowerment. In order to expand conservation areas beyond already established PAs, environmental NGOs often purchased land via EU funding programmes during the 1990s (Pinto and Partidário 2012). In sum, a multi-actor and multilevel governance context emerged as the 20th century came to an end.

Currently, five different categories exist for the management of PAs: national parks, natural parks, nature reserves, protected landscapes and nature monuments. According to the present legislation, they are characterised by different features and management objectives. Specifically:

i. National parks are intended to protect representative sites of natural regions, humanised and natural landscapes and geological sites, with scientific, ecological or educational values. Active management objectives include species recovery and the promotion of alternative activities for local sustainable development.

ii. Natural parks provide the conditions for the preservation of ecosystems created through sustainable human activities. Their management also aims to contribute to regional and local development.

iii. Nature reserves cover areas characterised by ecological, geological and physiographic features and are not permanently or significantly inhabited, in order to preserve them unaltered by human activities.

iv. Protected landscapes cover areas produced by a balanced interaction of people and nature. Their objective is to ensure the protection of significant aesthetic, ecological or cultural values, for example through the promotion of local traditional sustainable practices.

v. Nature monuments are established to set aside relatively small areas characterised by outstanding natural features (e.g. geological formations) with ecologic, aesthetic, scientific or cultural value.

Instead, the governance categories we will focus on are the following: i) national PAs, that are managed by state actors, in particular by the National Authority; ii) regional and local PAs managed by local authorities and iii) private PAs managed by private actors. Their genesis and characteristics are detailed below. National PAs can be classified under one of the five management categories mentioned above, while regional and local PAs can adopt whichever designation, except for the national park classification (see Figure 1).

The management structures have undergone changes over time. However, they are not generally dependent on the management categories (which have also altered over time, see Pinto and Partidário 2012) but on the governance categories (detailed in the following sections). Nature monuments are an exception, since they are small areas directly managed by the National Authority. Moreover, as regards restrictions and management objectives, it is important to note that Decree-Law n. 19/93 established the obligation of a spatial plan for national and local/regional PAs (except for nature monuments); until then most PAs were managed based on a list of regulations published in the designation act. Successively, Decree-Law n. 142/2008 removed the requirement for spatial plans for all PAs except national parks and nature national parks ${ }^{6}$.

The national network of PAs, which will be the focus of our analysis, is complemented by, and often overlaps with, the Natura 2000 sites and other classified areas 


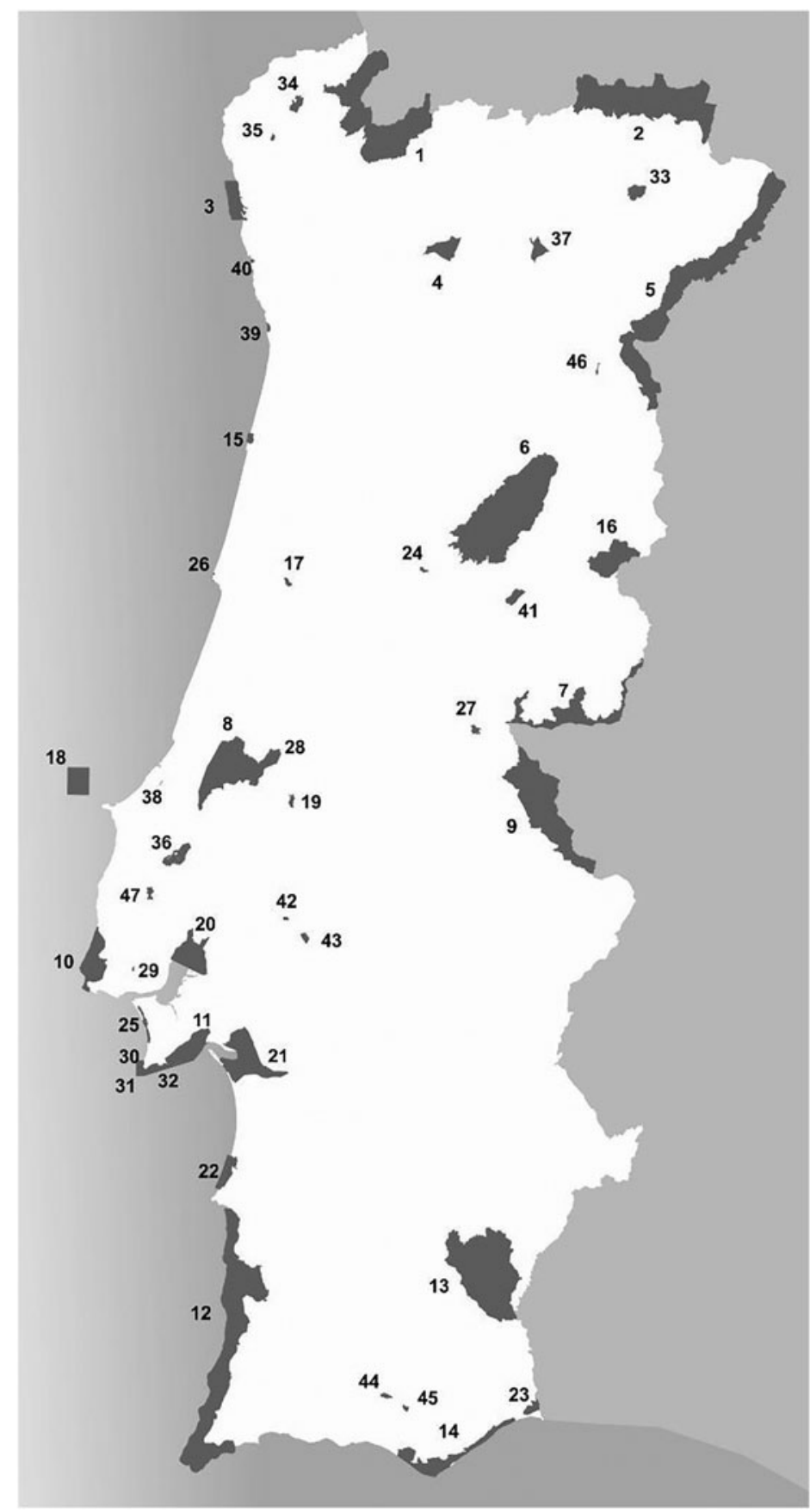

Figure 1. Portuguese national network of PAs. (Portuguese mainland) Notes: 32 national PAs, identification number (ID): from 1 to 32 (1 national park, ID $1 ; 13$ natural parks, ID from 2 to $14 ; 9$ nature reserves, ID, from 15 to $23 ; 2$ protected landscapes, ID 24 and 25; 7 natural monuments, ID from 26 to 32). 14 local and regional PAs, ID: from 33 to 45 and 47. (1 natural park, ID 37; 2 nature reserves, ID, 38 and 39; 11 protected landscapes, ID from 33 to 36, from 40 to 45 and 47). One Private PA, ID: 46. Source: elaborated from http:// www2.icnf.pt/portal/ap/rnap accessed 20/03/2018. 
established under international commitments (e.g. Ramsar sites). The Natura 2000 network, established to nationally implement the EU Habitats and Birds Directives, covers approximately $22 \%$ of the Portuguese terrestrial area. The sectoral plan establishing the orientations for the preservation of natural values in Natura 2000 areas, was adopted in 2008 after a public hearing process. The National Authority, local authorities and other authorities with relevant territorial and sectoral jurisdiction in the areas are responsible for the management of Natura 2000 sites. While the Natura 2000 network is not directly analysed in this paper it is important to highlight that its governance makes the case for the Europeanisation of nature conservation policies.

\section{Findings}

Tables 2 and 3 present the changes in involvement for state and non-state actors in the three selected phases of the decision-making process regarding PAs' i) designation ii) introduction of restrictions iii) management structure - between 1970 and 2015. Two main intertwined patterns of changes have been identified: i) a shift towards more inclusive approaches, both in terms of public participation and the inclusion of local authorities in the local decision-making processes for the management of national PAs (with a recent step back); ii) the emergence of PAs created and managed by local public actors and private actors. Regarding the latter, the Decree-Law n. 19/93 began a shift from a single governance model (national PAs) to three governance models that encompass national PAs, local and regional PAs and PAs with private statute (see Table 3). This change has broadened PAs' designation options, giving local authorities, private landowners, and (according to the current legislation) private actors managing private lands, the right to establish and manage a PA that is integrated into the national network.

\subsection{National protected areas: deepening stakeholder involvement?}

As regards national PAs, which are managed by state actors, our analysis reveals a gradual shift from a top-down approach, to the introduction of rules that promote nonstate actors' involvement in the decision-making process.

It is worth noting that, the first Protected Areas Act established that the inhabitants of National Parks would receive compensation for the loss of land profitability due to restrictions. However, this provision remained unimplemented. Moreover, the PenedaGerês National Park was established and managed by government actors (Forestry Services) through a top-down approach. As a result of the transition from the authoritarian to the democratic regime, the non-obligatory presence of local authorities in the consultative body of the National Park (and other upcoming PAs) gained a substantial and distinct connotation, as they became the democratically elected representatives of local communities. Nevertheless, until the enactment of the Decree-Law n. 19/93, the decision-making power, regarding: (i) the designation of a PA; (ii) its restrictions and (iii) its management, mainly remained in the hands of state actors.

In particular, the Decree n. 4/78 stated that each PA would have a director, designated by the president of the National Authority, holding management powers (e.g. issuing authorisations for activities limited by the PA regulations) and supported by two consultative bodies: a general commission with local and central authorities, representatives and a scientific commission (see Table 4). However, this model was not compulsory; its application depended on each PA's importance and extension. 
Table 2. The involvement of state and non-state actors in the governance of national PAs.

\begin{tabular}{|c|c|c|c|c|c|c|c|c|c|}
\hline & 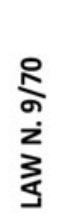 & $\begin{array}{l}\stackrel{\circ}{\hat{m}} \\
\underset{6}{6} \\
\dot{z} \\
\dot{0} \\
\dot{0}\end{array}$ & 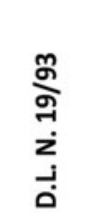 & 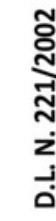 & & 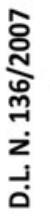 & 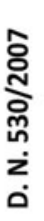 & z & \\
\hline & \multirow[t]{2}{*}{ NPA } & \multirow[t]{2}{*}{ NPA } & NPA & \multirow{2}{*}{\multicolumn{2}{|c|}{ NPA }} & \multicolumn{2}{|c|}{ NPA } & \multicolumn{2}{|c|}{ NPA } \\
\hline & & & A & & & A & $B$ & A & B \\
\hline \multicolumn{10}{|l|}{ State Actors } \\
\hline Designation & & & & $x$ & $x$ & $x$ & $x$ & & \\
\hline Restrictions & & & & \multicolumn{2}{|c|}{$x$} & \multicolumn{2}{|c|}{$x$} & & \\
\hline Management & & & & \multicolumn{2}{|c|}{$x$} & & & & \\
\hline \multicolumn{10}{|l|}{ Local Authorities } \\
\hline \multicolumn{10}{|l|}{ Designation } \\
\hline Restrictions & & & & \multicolumn{2}{|c|}{$\mathrm{x}$} & \multicolumn{2}{|c|}{$\mathrm{x}$} & & \\
\hline \multicolumn{10}{|l|}{ Management } \\
\hline \multicolumn{10}{|l|}{ Envi. NGOs } \\
\hline \multicolumn{10}{|l|}{ Designation } \\
\hline Restrictions & & & & \multicolumn{2}{|c|}{$x$} & \multicolumn{2}{|c|}{$x$} & & \\
\hline Management & & & & \multicolumn{2}{|c|}{$x$} & \multicolumn{2}{|c|}{$\mathrm{x}$} & & \\
\hline \multicolumn{10}{|l|}{ Citizens (local communities) } \\
\hline \multicolumn{10}{|l|}{ Designation } \\
\hline Restrictions & & & & \multicolumn{2}{|c|}{$x$} & \multicolumn{2}{|c|}{$x$} & & \\
\hline Management & & & & \multicolumn{2}{|c|}{$x$} & \multicolumn{2}{|c|}{$x$} & & \\
\hline \multicolumn{10}{|l|}{ Other Stakeholders } \\
\hline \multicolumn{10}{|l|}{ Designation } \\
\hline Restrictions & & & & \multicolumn{2}{|c|}{$\mathrm{x}$} & \multicolumn{2}{|c|}{$X$} & & \\
\hline Management & & & & \multicolumn{2}{|c|}{$x$} & & & & \\
\hline
\end{tabular}

Notes: NPA = national protected areas (A) refer to national PAs designated by national authority; (B) refers to national PAs' designation proposed by local authorities or private actors.

* The consultative bodies with representatives of local authorities and NGOs were not mandatory, depending on the importance of the PA.

** According to the Decree-Law n. 136/2007 the advisory commission of the National Authority encompasses, among other members, two representatives of environmental NGOs as well as representatives of the association of local authorities and of stakeholders" organisations. We assume that they are "directly" consulted in case of a new national PA designation.

*** According to the Decree-Law n. 221/2002 the consent of the consultative body was required to grant an authorisation for specific activities listed in the spatial plan. We highlight the shifting role of the local authority category, amongst other members of the consultative body, because the decree-law was specifically adopted to improve local authorities' power.

Decree-Law n. 242/2015 is not analysed in this table, since it introduced clarifications, especially on local and regional PAs (see Table 3). It also defined the transposition of national PA plans into spatial plans at the municipal level. However, this amendment has not yet been enforced due, in part, to some opposition from civil society organisations. 
Table 3. The involvement of state and non-state actors: local and regional PAs and private PAs.

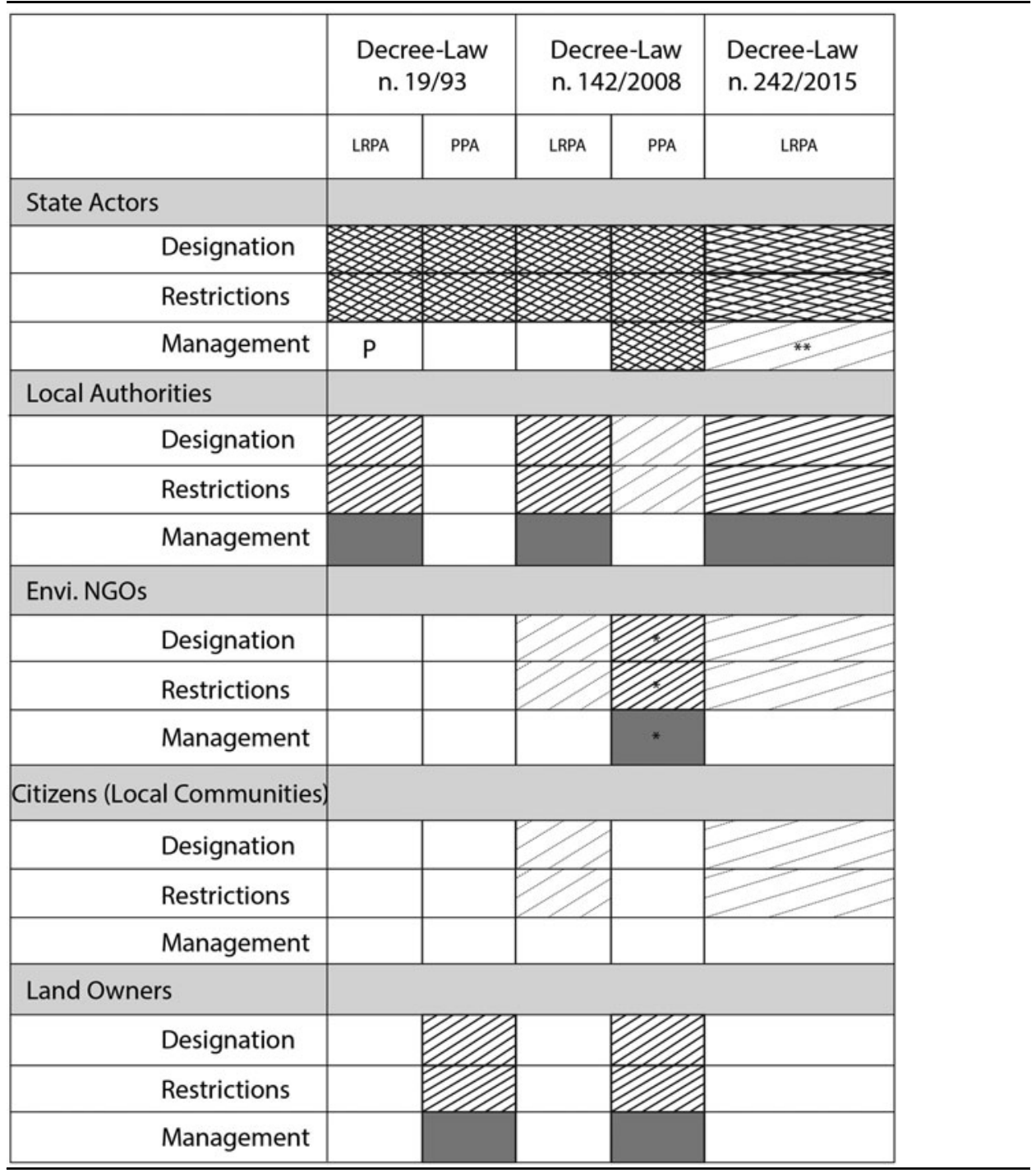

Notes: LRPA local and regional protected areas; PPAs private protected areas.

* NGOs can request the recognition of a private PA as private landowners or managers.

** The participation of the National Authority in the elaboration of the management regulation, defining the applicable restrictions and management rules is not compulsory.

(P) The institutional model applied by local and regional PAs created under the 1993 Act, imitated the one required for national PAs, with a directive commission chaired by a local authority representative where also sits a member appointed by the National Authority.

\subsubsection{Local authorities' involvement in national PAs}

The Decree-Law n. 19/93 established the inclusion of a local authority's representative in the executive commission for each national PA, also including its president, appointed by the Ministry of the Environment and a National Authority official (see Table 4). Due to the commission composition and the casting vote of its president, the 
Table 4. Management structures of national PAs.

\begin{tabular}{|c|c|c|c|}
\hline & Decree n. 4/78 & Decree-Law n. 19/93 & $\begin{array}{l}\text { Decree-Law n. 136/2007 } \\
\text { Decree n. 530/2007 }\end{array}$ \\
\hline Direction & $\begin{array}{l}\text { A director appointed by } \\
\text { the State Secretary for } \\
\text { the environment under } \\
\text { proposition of the NA } \\
\text { (among its technicians) }\end{array}$ & $\begin{array}{l}\text { Executive commission } \\
\text { (EC): } \\
\text { (i) President appointed by } \\
\text { the Ministry for the } \\
\text { environment under } \\
\text { proposition of the NA. } \\
\text { He had a casting vote } \\
\text { (ii) a representative of } \\
\text { local authorities } \\
\text { (iii) a member appointed } \\
\text { by the NA } \\
\text { Decree-Law n. } 221 / 2002 \text { : } \\
\text { President appointed by } \\
\text { the responsible Ministry } \\
\text { and local authorities' } \\
\text { legally-binding opinion } \\
\text { on the initial EC } \\
\text { appointment }\end{array}$ & $\begin{array}{l}\text { A director for each } \\
\text { regional department } \\
\text { encompassing national } \\
\text { PAs and Natura } 2000 \\
\text { sites } \\
\text { ( } 5 \text { regional departments } \\
\text { and a department for } \\
\text { wetlands areas) } \\
\text { The directors are } \\
\text { appointed by the } \\
\text { Ministry for the } \\
\text { environment }\end{array}$ \\
\hline $\begin{array}{l}\text { Consultative } \\
\text { Bodies }\end{array}$ & $\begin{array}{l}\text { i) General Commission: } \\
\text { chaired by the director } \\
\text { and composed of local } \\
\text { authorities } \\
\text { representatives and } \\
\text { members of public } \\
\text { administrative services } \\
\text { ii) Scientific commission: } \\
\text { with representatives of } \\
\text { cultural and heritage } \\
\text { associations, } \\
\text { universities, } \\
\text { research institutes }\end{array}$ & $\begin{array}{l}\text { Advisory commission: with } \\
\text { representatives of } \\
\text { scientific institutions, } \\
\text { central administration, } \\
\text { local authorities and } \\
\text { associations for } \\
\text { environment and } \\
\text { heritage preservation } \\
\text { Decree-Law n. } 213 / 97 \\
\text { added representatives of } \\
\text { socio- } \\
\text { economic activities }\end{array}$ & $\begin{array}{l}\text { Advisory commission (one } \\
\text { for each PA): with } \\
\text { representatives of the } \\
\text { NA, local authorities, } \\
\text { environmental NGOs, } \\
\text { scientific institutions, } \\
\text { members appointed by } \\
\text { central administration } \\
\text { services } \\
\text { Decree-Law n. } 78 / 2015 \\
\text { added representatives of } \\
\text { socio- } \\
\text { economic activities }\end{array}$ \\
\hline
\end{tabular}

Note: NA = National Authority.

local authority representative did not make a final decision on management issues; however, this model allowed a direct platform for discussion between the three members. The 1993 legislation was a turning point, since it also formally recognised the right of local authorities and private actors to propose the establishment of a national PA. It is important to mention that some PAs were previously established as a result of local authorities' requests and NGOs' demands (see in Pinto and Partidário 2012). Moreover, the Decree-Law stated that spatial plans, compulsory for national PAs (except for nature monuments, see above), would be elaborated by the National Authority together with competent ministries and local authorities.

Despite these positive developments, it is worth noting that the involvement of local authorities is somehow 'intermittent' and seems to be associated with political cycles and governments' decentralisation agenda. If Decree-Law n. 19/93 allowed for local authorities' involvement in the establishment and management of PAs, Decree-Law n. 221/2002 further empowered local authorities, introducing their legally binding opinion on the initial 
appointment of the executive commission. The competences of the consultative body were also enhanced, as well as the power of the local authorities among their constituent members. In particular, the act stated that the president would be elected from the representatives of local authorities, and the consent of the consultative body would be required to authorise specific activities subject to conditions, listed in the PA plan. These alterations were introduced according to the administrative decentralisation principle stated by the previous Local Government Act (Law n. 159/99, 14 September 1999).

A decrease in local authorities' involvement is represented by the Decree-Law n. 136/ 2007, the main goal of which was to rationalise human and financial resources in the light of a systematic technical effectiveness increase. This reform took place within the context of a progressive loss of status, financial difficulties and a decrease in the number of technicians from the National Authority, which began in the early 2000s (see Pinto and Partidário 2012), and which the 2007-2008 global financial crisis worsened. In particular, the 2007 Decree-Law removed the executive commission of national PAs. It also established the substitution of the president of the executive commission with a regional director who had, and still has, management powers over national PAs and Natura 2000 sites included within the same geographical area. However, each national PA maintains a consultative body with advisory functions (see also Table 4). Remarkably, this centralisation removed the more direct institutional channel that allowed local authorities to participate in management decision making. In addition, it strained their interaction with current "regional" directors who were, and still are, required to address issues related to numerous, and eventually heterogeneous, PAs due to their regional spheres of competences.

Moreover, it is important to mention that the advisory commission of the National Authority, created by Decree-Law n. 136/2007, and conceived for consultation on the definition of the authority's lines of actions, includes, among other members, representatives of the national association of local authorities.

\subsubsection{NGO involvement in national PAs}

Contrastingly, the involvement of NGOs in national PA designation, definition of restrictions and management has been regular. Even if in the 1970 National Act there was no reference to NGO involvement, the first National Park included NGOs in its consultative body. In any case, as shown in Table 2, NGOs have had a consultative role in the governance arrangements of PAs formally recognised and promoted in national legislation. However, as far as the 2007 reform is concerned, a representative of a national environmental NGO clarified that: "It corresponded to a centralisation shift which reduced communication opportunities and channels for NGOs and thus their capacity to influence." As part of the civil society, NGOs have also been given the opportunity to express their views through the public hearing process. In addition, since 2007, two representatives of environmental NGOs have been included in the advisory commission of the National Authority.

\subsection{The decentralisation of protected areas' establishment and management: local and regional protected areas}

In 1993, local and regional PAs were recognised as alternative governance models to national ones, with the purpose of protecting and sustaining natural, cultural and 
aesthetic values considered relevant at local level. As pointed out by a National Authority official:

There was some interest from local authorities to establish and manage protected areas and we (the National Authority) started to realise that we did not have the capacity to be in all of them.

Regarding the motivations and factors that have facilitated their emergence, another National Authority official specified:

Why did these local protected areas start appearing? Some of them because of environmental sensibility (...) However, many of them were incentivised by the existence of European Community funding. That is, the EU programs at national level began to be developed in order to recognise a funding increase for the areas integrated into the national network and this led to the emergence of some local and regional PAs.

Similarly to private PAs, local PAs created and managed by local authorities (single local authority in the case of local PAs and an association of local authorities or intermunicipal community in the case of regional PAs) need to be recognised by the National Authority for their integration into the national network.

Importantly, one of the alterations to the Decree-Law n. 142/2008, introduced by the Decree-Law n. 242/2015, clarified that for their integration into the network, local and regional PAs have to receive a positive assessment from the National Authority, which regularly evaluates the maintenance of the preconditions for the designation. Moreover, the law clarifies that local authorities should promote the participation of the National Authority in the elaboration of the management regulation, in order to best ensure the articulation of management plans with spatial plans and other rules applicable in that territory. It is also important to note that the directive commission of local PAs established under the Decree-Law n.19/93, contained a representative of the National Authority. This model, imitating the one at that time for national PAs, was not followed by the more recent local and regional PAs, thus removing a connection between local actors and state actors on this scale.

\subsection{The privatisation of protected areas' establishment and management}

The creation of a distinct governance model allowing for the statutory recognition of protected sites managed by private actors goes back to the designation of ornithological reserves aiming at protecting bird species from hunting under the Decree-Law n. 264/79. This designation was an opportunity for landowners before the "non-hunting right" recognition in 2004, which gave them the right to request a hunting ban on their lands. Nevertheless, just one ornithological reserve was classified. As clarified by an NGO representative:

In order to have the protected site recognised it was necessary to present a scientific report, usually done by a competent entity (... ) it required an expensive process. It was an administrative obstacle that may explain the lack of candidates.

Successively the 1993 Decree-Law gave private PAs a slightly different designation. Private landowners could voluntarily propose the creation of a protected site on 
their land, aiming at conserving species or habitats. After the evaluation by the National Authority, the area would be classified by a national decree as a "site of biological interest", managed by a policy officer indicated by the landowner. Some of the areas created with this classification were successively reclassified as local PAs.

Private PAs are currently regulated under the framework of the Decree-Law n. 42/ 2008, in particular by the Decree n. 1181/2009. It requires that private PAs' designation is voluntarily requested by the landowner, an environmental NGO or another legal person under private law (e.g. non-profit association) and the owner has agreed to the submission of the application. Conservation activities planned for the area must comply with the objectives stated by national laws. The National Authority assesses the recognition request based on stated criteria, eventually consulting the local authorities where the requested PA is located. If the request is approved, the National Authority monitors the perpetuation of the designation requirements in order to ensure long-term commitment for conservation. In particular, the public-private partnership is enshrined in a protocol defining the rights and responsibilities of the National Authority and the private actor ${ }^{7}$.

\subsection{Public participation in the governance of protected areas}

Regarding citizens and local communities, a diachronic legislation analysis shows an increase in the promotion of their direct involvement in all three governance models for PAs. Decree-Law n. 613/76, already mentioned the consultation of local populations as regards the definition of the protected area zoning (areas with distinct protection levels according to nature conservation objectives). However, Decree-Law n. 19/ 93 required a public hearing on the establishment of PAs as well as on the process of adopting the spatial plan, defining permitted and prohibited actions. The involvement of representatives of stakeholders with relevant socio-economic interests in the area was promoted a few years later when they were included in the consultative body of each national PA (see also Table 4). Since 2007 they have also been part of the advisory commission of the National Authority.

\section{Discussion}

Our study shows the increased opportunities for stakeholders and local communities in engaging with the governance of Portuguese PAs. Along with the implementation of participatory provisions, the opening up of decision-making processes has resulted in the emergence of non-hierarchical governance arrangements, giving non-state actors (mainly local authorities and NGOs) more power for the creation and management of PAs. These findings are in line with those of European countries, especially those with a tradition of administrative centralism (Niedziałkowski et al. 2016; KluvankovaOravska et al. 2009; Hongslo et al. 2016) and with the global trend for the governance of PAs (Dearden, Bennett, and Johnston 2005).

This evolution has corresponded to a reconfiguration of the Portuguese state role that seems to have changed as a result of: i) the existence of multilateral environmental agreements (e.g. the Convention for Biological Diversity- CBD); ii) the Europeanisation of decision-making processes, along with the existence of EU funds for non-state actors' projects with nature conservation purposes and for regional development. Note, the legal framework for the designation of local, regional and private PAs dates back to 1993, following the 1992 UN Conference on Environment and 
Development where the CBD was opened for signatures. Peculiar to the Portuguese case, the driver for decentralisation requests at national level may have gone beyond nature conservation, although this requires further investigation. Despite these governance innovations, the analysis of de jure governance settings suggests that while configuring new partnerships with local authorities and private landowners, the National Authority seems to have retained its steering role. For example, it attempts to 'govern at distance' (see Sørensen and Torfing 2016) through public/private partnerships, defined by contracts and the monitoring of actions, and through its (non-obligatory) participation in the elaboration of the management regulation for local and regional PAs, replicating the existent institutional path dependence (Hongslo et al. 2016).

It could be argued that, thanks to the restructuring of its role, the state has been able to increase its territorial range of authority in areas voluntarily designed by local governments and private actors. Although, it should be questioned to what extent the arrangements in place are able to tackle, in an integrated way, cross-scale issues and create room for the process of adaptive co-governance (Plummer et al. 2012), especially considering the reduction of resources faced by the National Authority.

Moreover, it is important to note that, governance models entailing a partnership with local authorities or private actors coexist with, but do not replace, the 'traditional' one (viz. national PAs). Co-governance arrangements introduced in 1993 partially draw on de-facto informal interactions (not yet codified in the legislation), between the National Authority, local authorities and NGOs. Also, private PAs that are currently in the embryonic phase of recognition and integration into the national network in some European countries, while largely promoted by international organisations (Stolton, Redford, and Dudley 2014), are not entirely new to governance settings in Portugal. They have existed since the late 1970s as opportunities for rural landowners to create hunter free areas. However, despite alterations, in terms of criteria for recognition and governance structure, their diffusion has always been very limited.

Another peculiar aspect concerns decentralisation: the reorientation of national PAs towards co-governance with local authorities has witnessed a relevant setback over the last decade. This occurred when the 2007 reform substituted the executive bodies of national PAs with regional directors. The increased distance between local authorities and regional directors raises questions about the lack of representation of local interests in the balance between conservation and local development. There is also a considerable risk of a blame-shifting increase, since local authorities, currently only represented in the consultative bodies of each national PA, may begin shifting responsibilities regarding definitions of restrictions and obligations rejected by local communities to central government decision makers.

However, recent developments (2017) in the governance of PAs, include the implementation of a pilot project in a Natural Park, which aims to test a new PA comanagement setting involving local authorities, an NGO, a local university and a business development association (see Schmidt et al. 2017).

Concerning regional and local PAs' designation, the logic underpinning the decentralisation of nature conservation management is that democratic local institutions are most likely to respond to local needs, because of their closer proximity. Local authorities' accountability to local populations is a key factor for democratic decentralisation that fosters local community involvement (Agrawal and Ribot 1999). However, areas affected by substantial rural depopulation will inevitably witness a weakening of this involvement. Moreover, as Young et al. (2012) specified, reduced government intervention in 
biodiversity management requires additional context-dependent conditions to achieve successful participatory management. For example, collaboration that fosters trust building has been found to facilitate participation, while the lack of 'participation culture' and power imbalances reduce the likelihood of socially equitable outcomes (de Vente et al. 2016). Thus, flexible institutional models adaptable to the social and institutional contexts are desirable, coupled with a new role for national and local administrations. Otherwise, as pointed out by Carlsson and Berkes $(2005,71)$, a co-management agreement "might be an attempt by the State to offload a regulatory function that has proven too expensive to manage."

To sum up, there appears to exist a contradiction between the centralisation/regionalisation of national PAs' management and the cession of decision-making rights from central administration to local authorities in the governance models for regional and local PAs. However, these apparently contradictory trends seem to illustrate a common rationale. As the drivers for change increase incrementally (e.g. influence of international organisations, external policy communities etc.), the national PA management authority seems to be fighting to retain its all-encompassing coordination role, while adapting to the need for increasing competencies and resources within a multilevel governance context.

Additionally, the involvement of non-state actors as partners for nature conservation policies has gone hand in hand with the growing opportunities for public participation, mainly driven by the EU and international environmental agenda. However, our findings indicate that while the range of actors who can participate in decision-making processes regarding PAs has progressively widened, their involvement has not been deepened likewise. Indeed, consultation stands as the main category for public participation. Besides representing a low level of involvement, consultation is also usually depicted as a topdown exercise that fails to engage most individuals affected. Furthermore, studies have found that participatory arrangements are often established to reduce conflict, demobilising dissenting local stakeholders (Maestre-Andrés, Calvet-Mir, and Apostolopoulou 2018). Additional research adopting a de-facto perspective is required to explore to what extent the above-mentioned pitfalls apply in Portuguese PAs.

The framework adopted for this study has proven a valid and easily adaptable tool for the systematisation and the diachronic analysis of Portuguese legislation on PAs, the development of which has resulted in a vast array of decree-laws and regulations. Complemented with a contextualisation of nature conservation policies and qualitative analysis of interviews, it helped to structure a critical analysis of governance dynamics aiming to unveil contradictions regarding the (re)shaping of partnerships and participation for PAs.

\section{Concluding remarks}

This paper addressed the involvement of non-state actors in the design, implementation and management of Portuguese PAs and scrutinised the respective restructuring of the state role. Our analysis showed that legal and policy frameworks for PAs have gradually opened up, allowing for broader participation of individuals and groups in decision-making processes that affect them directly. What started during the authoritarian regime with the designation of a national park inspired by the US exclusionary model has been gradually altered by successive strands of legislation. Provisions for incremental democratisation (e.g. public hearings) were embedded, along with governance rescaling measures, often institutionalising existing informal relationships between state and non-state actors. Furthermore, in line with a wider European trend, and against the 
backdrop of increased intervention by actors in nature conservation, formal partnerships between central state, local authorities and private actors have multiplied.

However, under the banner of rationalising state resources, a contested recentralisation reform took place in 2007, limiting local authorities' participation in the management of PAs.

On one hand, the restructuring of the state's role, starting in the $1990 \mathrm{~s}$, seems to respond to its need to retain control and institutional fit while adapting to a dynamic multilevel governance and bottom-up requests. Under the context of limited public resources and increasing obligations, partnerships between local public actors and private actors are claimed to help by mobilising non-state actors' resources. In particular, the professionalisation of nature conservation NGOs, that sidesteps national jurisdiction to find funding opportunities at an international level, seems a relevant factor in explaining the emergence of the more recent regulation of private PAs. Similarly, local government actors may be seen as key players in making the maximum use of EU subsidies (see Apostolopoulou et al. 2014).

However, the shift from government to governance, entailing decentralisation or public/private partnerships, tends to not necessarily pave the way towards communitycentred conservation. This change would call for the implementation of a new political space and collaborative relationships that foster social learning, the reach of collective decisions and power redistribution. Concurrently, public actors, at national and local levels, need new resources for adaptive co-governance. This need goes beyond the traditional enforcement expenditure typical of regulatory approaches; it calls for cultural and organisational transformations.

\section{Acknowledgements}

The authors thank three anonymous referees for their constructive comments which helped to improve the paper. The authors also thank Dr. Damián Copena for reviewing an early version of this paper and are deeply grateful to interviewees for sharing their knowledge and time and for helping in the collection of information.

\section{Disclosure statement}

No potential conflict of interest was reported by the authors.

\section{Notes}

1. In this paper by state actors we refer to central administration (national level) or decentralised bodies of the central administration (i.e. regional agencies).

2. Due to the NGO role in nature conservation policy design.

3. An independent body that has the aim of advising public actors and civil society on matters related to environment and sustainability.

4. Law n. 11/87, 7 April 1987.

5. Law n. 10/87, 4 April 1987.

6. For nature reserves and protected landscapes a spatial plan is mandatory when indicated in the piece of legislation that establishes them. Currently, 25 PAs have spatial plans in force. For an updated list see http://www2.icnf.pt/portal/pn/biodiversidade/ordgest/poap

7. To date, just one private PA has been recognised and integrated into the national network. This is the Faia Brava Reserve which was legally recognised in 2010 and is owned and managed by an NGO. Other sites managed by NGOs were incorporated into national PAs or became local PAs. For instance areas owned and managed by a national NGO are part of the Tejo Internacional Natural Park, while a site managed by a national NGO and a local 
environmental association was designated in 2009 as the local natural reserve of Paul da Tornada. Few other sites managed by NGOs are part of Natura 2000 classified areas.

\section{Funding}

The first author also acknowledges the financial support of the Portuguese Fundação para a Ciência e a Tecnologia through the scholarship PD/BD/106025/2014 and through the $\mathrm{PhD}$ Program on Global Studies PD/FCT 00419/2012. CENSE - Center for Environmental and Sustainability Research is financed by Fundação para a Ciência e a Tecnologia (UID/AMB/ 04085/2019).

\section{ORCID}

Giulia Iannuzzi (D) http://orcid.org/0000-0002-3353-7299

Rui Santos (D) http://orcid.org/0000-0003-2829-6475

João Morais Mourato (D) http://orcid.org/0000-0003-0891-4897

\section{References}

Agrawal, A., and J. Ribot. 1999. "Accountability in Decentralization: A Framework with South Asian and West African Cases." The Journal of Developing Areas 33 (4): 473-502.

Apostolopoulou, E., D. Bormpoudakis, R. Paloniemi, J. Cent, M. Grodzińska-Jurczak, A. Pietrzyk-Kaszyńska, and J.D. Pantis. 2014. "Governance Rescaling and the Neoliberalization of Nature: The Case of Biodiversity Conservation in Four EU Countries." International Journal of Sustainable Development and World Ecology 21 (6): 481-494. doi:10.1080/ 13504509.2014.979904.

Armitage, D., R. de Loë, and R. Plummer. 2012. "Environmental Governance and Its Implications for Conservation Practice." Conservation Letters 5 (4): 245-255. doi:10.1111/j. 1755-263X.2012.00238.x.

Arnstein, S.R. 1969. "A Ladder of Citizen Participation." Journal of the American Institute of Planners 35 (4): 216-224. doi:10.1080/01944366908977225.

Beierle, T.C., and J. Cayford. 2002. Democracy in Practice: Public Participation in Environmental Decisions. Washington, DC: Resources for the Future.

Berkes, F. 2007. "Community-Based Conservation in a Globalized World." Proceedings of the National Academy of Sciences of Sciences 104 (39): 15188-15193. doi:10.1073/pnas. 0702098104.

Berkes, F. 2009. "Evolution of Co-Management: Role of Knowledge Generation, Bridging Organizations and Social Learning." Journal of Environmental Management 90 (5): 1692-1702. doi:10.1016/j.jenvman.2008.12.001.

Bishop, P., and G. Davis. 2002. "Mapping Public Participation in Policy Choices." Australian Journal of Public Administration 61 (1): 14-29. doi:10.1111/1467-8500.00255.

Bulkeley, H., and A.P.J. Mol. 2003. "Participation and Environmental Governance: Consensus, Ambivalence and Debate." Environmental Values 12 (2): 143-154. doi:10.3197/ 096327103129341261.

Carlsson, L., and F. Berkes. 2005. "Co-Management: Concepts and Methodological Implications.” Journal of Environmental Management 75 (1): 65-76. doi:10.1016/j.jenvman. 2004.11.008.

Cleaver, F. 1999. "Paradoxes of Participation: Questioning Participatory Approaches to Development." Journal of International Development 11 (4): 597-612. doi:10.1002/ (SICI)1099-1328(199906)11:4<597::AID-JID610>3.0.CO;2-Q.

Corson, C., R. Gruby, R. Witter, S. Hagerman, D. Suarez, S. Greenberg, M. Bourque, N. Gray, and L.M. Campbell. 2014. "Everyone's Solution? Defining and Redefining Protected Areas at the Convention on Biological Diversity." Conservation and Society 12 (2): 190-202. doi: 10.4103/0972-4923.138421.

Dearden, P., M. Bennett, and J. Johnston. 2005. "Trends in Global Protected Area Governance, 1992-2002.” Environmental Management 36 (1): 89-100. doi:10.1007/s00267-004-0131-9. 
DeCaro, D.A., and M.K. Stokes. 2013. "Public Participation and Institutional Fit: A Social-Psychological Perspective." Ecology and Society 18 (4): 40. doi:10.5751/ES-05837-180440.

de Vente, J., M.S. Reed, L.C. Stringer, S. Valente, and J. Newig. 2016. "How Does the Context and Design of Participatory Decision-Making Processes Affect Their Outcomes? Evidence from Sustainable Land Management in Global Drylands." Ecology and Society 21 (2): 24. doi: $10.5751 / \mathrm{ES}-08053-210224$.

Ferranti, F., E. Turnhout, R. Beunen, and J.H. Behagel. 2014. "Shifting Nature Conservation Approaches in Natura 2000 and the Implications for the Roles of Stakeholders." Journal of Environmental Planning and Management 57 (11): 1642-1657. doi:10.1080/09640568.2013. 827107.

Figueiredo, E., T. Fidélis, and A. Rosa Pirez. 2001. "Grassroots Environmental Action in Portugal (1974-1994)." In Environmental Politics in Southern Europe: Actors, Institutions and Discourses in a Europeanizing Society, edited by K. Eder and M. Kousis, 197-221. Dordrecht: Kluwer Academic Publishers.

Giessen, L., S. Burns, M.A.K. Sahide, and A. Wibowo. 2016. "From Governance to Government: The Strengthened Role of State Bureaucracies in Forest and Agricultural Certification." Policy and Society 35 (1): 71-89. doi:10.1016/j.polsoc.2016.02.001.

Hatcher, A., S. Jaffry, O. Thebaud, and E. Bennett. 2000. "Normative and Social Influences Affecting Compliance with Fishery Regulations." Land Economics 76 (3): 448-461. doi:10. 2307/3147040.

Héritier, S. 2010. "Public Participation and Environmental Management in Mountain National Parks." Revue de Géographie Alpine / Journal of Alpine Research [En ligne]: 98-1. doi:10. 4000/rga.1156.

Hongslo, E., S. Hovik, A. Zachrisson, and A.K.A. Lundberg. 2016. "Decentralization of Conservation Management in Norway and Sweden: Different Translations of an International Trend." Society and Natural Resources 29: 998-1014. doi:10.1080/08941920.2015.1086456.

Hovik, S., C. Sandstrom, and A. Zachrisson. 2010. "Management of Protected Areas in Norway and Sweden: Challenges in Combining Central Governance and Local Participation." Journal of Environmental Policy and Planning 12 (2): 159-177. doi:10.1080/ 15239081003719219.

Jeanrenaud, S. 2002. People-Oriented Approaches in Global Conservation: Is the Leopard Changing Its Spots? London: International Institute for Environment and Development and Brighton; Institute for Development Studies.

Kluvankova-Oravska, T., V. Chobotova, I. Banaszak, L. Slavikova, and S. Trifunovova. 2009. "From Government to Governance for Biodiversity: The Perspective of Central and Eastern European Transition Countries." Environmental Policy and Governance 19: 186-196. doi: 10.1002/eet.508.

Knill, C., and D. Lehmkuhl. 2002. "Private Actors and the State: Internationalization and Changing Patterns of Governance." Governance 15 (1): 41-63. doi:10.1111/1468-0491. 00179.

Kooiman, J. 2003. Governing as Governance. London: SAGE.

Laclau, E., and C. Mouffe. 2001 [1985]. Hegemony and Socialist Strategy: Towards a Radical Democratic Politics. London: Verso.

Lane, M.B. 2003. "Decentralization or Privatization of Environmental Governance? Forest Conflict and Bioregional Assessment in Australia." Journal of Rural Studies 19 (3): 283-294. doi:10.1016/S0743-0167(02)00084-0.

Langholz, J.A., and J.P. Lassoie. 2001. "Perils and Promise of Privately Owned Protected Areas." BioScience 51 (12): 1079-1085. doi:10.1641/0006-3568(2001)051[1079:PAPOPO.2.0.CO;2]

Larsen, P.B., and D. Brockington. 2017. "Introduction: Rethinking the Boundaries of Conservation NGOs." In The Anthropology of Conservation NGOs, edited by P.B. Larsen and D. Brockington, 1-15. Cham, Switzerland: Palgrave Macmillan.

Lockwood, M. 2010. "Good Governance for Terrestrial Protected Areas: A Framework, Principles and Performance Outcomes." Journal of Environmental Management 91 (3): 754-766. doi:10.1016/j.jenvman.2009.10.005.

Maestre-Andrés, S., L. Calvet-Mir, and E. Apostolopoulou. 2018. "Unravelling Stakeholder Participation under Conditions of Neoliberal Biodiversity Governance in Catalonia, Spain.” Environment and Planning C: Politics and Space 36 (7): 1299-1318. doi:10.1177/ 2399654417753624. 
Mellinger, L., and D. Floriani. 2015. "Democratic Participation in the Management of Common Natural Resources and the Native Populations in the Southern Coast of Paraná." Ambiente and Sociedade 18 (2): 1-22. doi:10.1590/1809-4422ASOCEx01V1822015en.

Niedziałkowski, K., J. Paavola, and B. Jędrzejewska. 2012. "Participation and Protected Areas Governance: The Impact of Changing Influence of Local Authorities on the Conservation of the Białowieża Primeval Forest, Poland." Ecology and Society 17 (1): 2. doi:10.5751/ES04461-170102.

Niedziałkowski, K., A. Pietrzyk-Kaszyńska, M. Pietruczuk, and M. Grodzińska-Jurczak. 2016. "Assessing Participatory and Multi-Level Characteristics of Biodiversity and Landscape Protection Legislation: The Case of Poland." Journal of Environmental Planning and Management 59 (10): 1891-1911. doi:10.1080/09640568.2015.1100982.

Paavola, J., A. Gouldson, and T. Kluvánková-Oravská. 2009. "Interplay of Actors, Scales, Frameworks and Regimes in the Governance of Biodiversity." Environmental Policy and Governance 19 (3): 148-158. doi:10.1002/eet.505.

Pellizzoni, L. 2003. "Uncertainty and Participatory Democracy." Environmental Values 12 (2): 195-224. doi:10.3197/096327103129341298.

Pinto, B., and M. Partidário. 2012. "The History of the Establishment and Management Philosophies of the Portuguese Protected Areas: Combining Written Records and Oral History." Environmental Management 49 (4): 788-801. doi:10.1007/s00267-012-9820-y.

Plummer, R., B. Crona, D.R. Armitage, P. Olsson, M. Tengö, and O. Yudina. 2012. "Adaptive co-Management: A Systematic Review and Analysis." Ecology and Society 17 (3): 11. doi: 10.5751/ES-04952-170311.

Rauschmayer, F., S. van den Hove, and T. Koetz. 2009a. "Participation in EU Biodiversity Governance: How Far Beyond Rhetoric?" Environment and Planning C: Government and Policy 27 (1): 42-58. doi:10.1068/c0703j.

Rauschmayer, F., J. Paavola, and H. Wittmer. 2009b. "European Governance of Natural Resources and Participation in a Multi-Level Context: An Editorial." Environmental Policy and Governance 19 (3): 141-147. doi:10.1002/eet.504.

Reed, M.S. 2008. "Stakeholder Participation for Environmental Management: A Literature Review.” Biological Conservation 141 (10): 2417-2431. doi:10.1016/j.biocon.2008.07.014.

Rhodes, R.A.W. 1996. "The New Governance: Governing Without Government." Political Studies 44 (4): 652-667. doi:10.1111/j.1467-9248.1996.tb01747.x.

Rodríguez-Izquierdo, E., M.C. Gavin, and M.O. Macedo-Bravo. 2010. "Barriers and Triggers to Community Participation across Different Stages of Conservation Management." Environmental Conservation 37 (3): 239-249.

Schmidt, L., J. Mourato, D. Travassos, and R. Calvário. 2017. “Áreas Protegidas: Que Modelo de Gestão?” Policy Brief 2017. Observa - Observatório de Ambiente, Território e Sociedade. Lisboa: Instituto de Ciências Sociais/CNADS - Conselho Nacional do Ambiente e do Desenvolvimento Sustentável.

Sørensen, E., and J. Torfing. 2016. "Metagoverning Collaborative Innovation in Governance Networks." The American Review of Public Administration 47 (7): 826-839. doi:10.1177/ 0275074016643181.

Soromenho-Marques, V. 1998. O futuro frágil: Os desafios da crise global de ambiente. Lisbon: Publicações Europa-America.

Stolton, S., K.H. Redford, and N. Dudley. 2014. The Futures of Privately Protected Areas. Gland, Switzerland: IUCN.

Turnhout, E., S. Van Bommel, and N. Aarts. 2010. "How Participation Creates Citizens: Participatory Governance as Performative Practice." Ecology and Society 15 (4): 26. doi:10. 5751/ES-03701-150426.

Wesselink, A., J. Paavola, O. Fritsch, and O. Renn. 2011. "Rationales for Public Participation in Environmental Policy and Governance: Practitioners' Perspectives." Environment and Planning A: Economy and Space 43 (11): 2688-2704. doi:10.1068/a44161.

Young, J.C., J.R.A. Butler, A. Jordan, and A.D. Watt. 2012. "Less Government Intervention in Biodiversity Management: Risks and Opportunities." Biodiversity and Conservation 21 (4): 1095-1100. doi:10.1007/s10531-012-0243-0.

Young, J.C., A. Jordan, K.R. Searle, A. Butler, D.S. Chapman, P. Simmons, and A.D. Watt. 2013. "Does Stakeholder Involvement Really Benefit Biodiversity Conservation?" Biological Conservation 158: 359-370. doi:10.1016/j.biocon.2012.08.018. 